\title{
Leptospirosis and brucellosis seroepidemiology in sheep and dogs from non-mechanized rural properties in the northwestern region in the state of Paraná
}

\section{Soroepidemiologia da leptospirose e brucelose em ovinos e cães de propriedades rurais não tecnificadas da região noroeste do estado do Paraná}

\author{
Leila Alves de Oliveira ${ }^{1}$; Melissa Marchi Zaniolo; Eduardo Herrera Dias²; \\ Hermes Bianki Silva Brandão ${ }^{3}$; Kariny Aparecida Jardim Rubio ${ }^{4}$; \\ Bruna Paula Martins Ferreira ${ }^{5}$; Aguinaldo Yoshio Nakamura ${ }^{1}$; \\ Roberta Torres Chideroli6; Julio Cesar de Freitas ${ }^{6}$; Daniela Dib Gonçalves ${ }^{7 *}$
}

\begin{abstract}
Sheep breeding has been important in agribusiness, transforming the Brazilian productive scenario. However, it is still deficient due to the damages caused by infectious diseases. Leptospirosis is a severe disease with global distribution, caused by bacteria from the Leptospira genre affecting both humans and animals. The general infection is unapparent, or its clinical signs, when present, are similar to other infections. Brucellosis is an infectious disease caused by bacteria from the Brucella genre responsible for reproductive disorders in animals, especially ruminants. The purpose of this paper was to seroepidemiological study of Leptospira spp. and Brucella ovis in sheep and dogs from nonmechanized rural properties from the northwestern region in the state of Paraná, Brazil. In order to detect anti-Leptospira antibodies, microscopic agglutination (MAT) was performed. For anti-Brucella antibodies, the agar gel immunodiffusion assay (AGID) was performed. From the total 542 samples from sheep sera analyzed, $11.25 \%$ were considered reagent to Leptospira spp. and $18.26 \%$ to Brucella ovis. From the 36 dog samples, $25 \%$ were reagent to MAT and AGID. From the 32 properties analyzed, $75 \%$ were considered positive for leptospirosis and $56.25 \%$ for brucellosis. Antibodies against the most probable serovars were Hardjo (34.42\%) and Butembo (44.44\%) in sheep and dogs, respectively, and the variable exchange of animals among properties was associated to leptospiric infection $(\mathrm{p}=0.028)$ in sheep. Leptospirosis and brucellosis are present in the sheep herd and dogs in the rural properties studied, and such result is a warning of the zoonotic importance and the need to establish sanitary programs directed to these animal species.
\end{abstract}

Key words: Brucella ovis. Risk factors. Infection. Leptospira spp. Zoonosis.

\footnotetext{
${ }^{1}$ Médicas Veterinárias, Discentes de Mestrado em Ciência Animal, Universidade Paranaense, UNIPAR, Umuarama, PR, Brasil. E-mail: jaconeti@hotmail.com; melissaz.vet@gmail.com; aguinaldovetuem@hotmail.com

2 Discente da Graduação de Medicina Veterinária, Universidade Estadual de Maringá, UEM, Umuarama, PR, Brasil. E-mail: eduhd_herreradias@hotmail.com

${ }^{3}$ Discente da Graduação de Medicina Veterinária, UNIPAR, Umuarama, PR, Brasil. E-mail: hermesbianki_brandao@hotmail.com

${ }^{4}$ Médica Veterinária, UNIPAR, Umuarama, PR, Brasil. E-mail: karinyemarcos@hotmail.com

5 Zootecnista, Discente do Mestrado em Ciência Animal, UNIPAR, Umuarama, PR, Brasil. E-mail: bp_ferreira@hotmail.com

${ }^{6}$ Médicos Veterinários, Doutorado, Programa de Pós-Graduação em Ciência Animal, Universidade Estadual de Londrina, UEL, Londrina, PR. E-mail: robertaa_tc@hotmail.com; freitasj@uel.br

${ }^{7}$ Médica Veterinária, Mestrado em Ciência Animal, UNIPAR, Umuarama, PR, Brasil. E-mail: danieladib@unipar.br

* Author for correspondence
} 


\section{Resumo}

A ovinocultura tem se destacado no agronegócio, transformando o cenário produtivo do Brasil, porém ainda possui uma deficiência devido aos danos causados por doenças infecciosas. A leptospirose é uma doença grave de distribuição mundial causada por bactérias do gênero Leptospira que afeta o homem e os animais. A infecção geralmente é inapetente, ou os sinais clínicos, quando presentes, são similares aos de outras infecções. A brucelose é uma enfermidade infecciosa causada por bactérias do gênero Brucella responsáveis por desordens reprodutivas nos animais, especialmente nos ruminantes. O objetivo deste trabalho foi realizar um estudo soroepidemiológico de Leptospira spp. e Brucella ovis ovinos e cães de propriedades rurais não tecnificadas da região noroeste do estado do Paraná, Brasil. Para detecção de anticorpos anti-Leptospira foi realizada a soroaglutinação microscópica (SAM), e para anticorpos anti-Brucella, a prova de imunodifusão em gel de ágar (IDGA). Das 542 amostras de soro ovino analisadas, foram consideradas reagentes 11,25\% para Leptospira spp. e 18,26\% para Brucella ovis. Das 36 amostras de cães, $25 \%$ foram regentes a SAM e IDGA. Das 32 propriedades, $75 \%$ foram consideradas positivas para leptospirose e $56,25 \%$ para brucelose. Os anticorpos contra os sorovares mais prováveis foram Hardjo $(34,42 \%)$ e Butembo $(44,44 \%)$ em ovinos e cães respectivamente, e a variável troca de animais entre propriedades foi associada à infecção leptospírica $(\mathrm{p}=0,028)$ nos ovinos. A leptospirose e a brucelose estão presentes no rebanho ovino e nos cães das propriedades rurais estudadas, e este resultado serve de alerta à sua importância zoonótica e a necessidade de estabelecer programas sanitários direcionados a esta espécie animal.

Palavras-chave: Brucella ovis. Fatores de Risco. Infecção. Leptospira spp. Zoonose.

\section{Introduction}

The production of small ruminants has presented a global growth in recent years (FARIAS et al., 2013) and sheep breeding has gained importance in the Brazilian agribusiness scenario. The country is considered the $8^{\text {th }}$ global producer, with a herd estimated in 14 million animals (MAPA, 2012). A productive increase of $10 \%$ between 2005 and 2012 is due to the easy handling of the herd, occupying a smaller area, and consuming less feed. It has become an alternative income source to small and medium rural producers (FARIAS et al., 2013).

In contrast to the development of sheep breeding, Brazil has encountered difficulties for its evolution due to damages caused by infectious diseases, mainly those caused by Leptospira spp. and Brucella ovis. These diseases are responsible for economic losses due to reproductive problems such as abortions, return to estrum, perinatal mortality, as well as being a public health and occupational issue (MELO et al., 2010; GONÇALVES et al., 2013; SANTOS et al., 2013).
Leptospirosis is a zoonotic disease caused by the Leptospira spp bacterium. This is a cosmopolitan disease, endemic mainly in tropical and subtropical climate (FAINE et al., 1999). This agent has a great number of serologic variants, which do not present host specificity, and can affect domestic and wild animals, as well as humans, representing, therefore, an important economic and public health issue (MELO et al., 2010; GRESSLER et al., 2012; FARIAS et al., 2013).

According to Melo et al. (2010), sheep can acquire the infection by exposure to the urine of infected animals or to the water, pasture and feed contaminated with Leptospira spp. In the animal, Leptospira spp. can penetrate wounded skin and/ or mucosa, spread through the blood stream and start multiplying in several organs. However, the bacterium has the kidneys as preferential organs, where it causes severe lesions. It is then transported by urine to contaminate the environment (FAINE et al., 1999; CARVALHO et al., 2011; GONÇALVES et al., 2013). 
Sheep leptospirosis can be manifested in an acute, chronic or asymptomatic form. Characteristic clinical symptoms are septicemia, hemorrhage and nephritis, followed by jaundice, hemoglobinuria, bloody mastitis, return to estrous, abortion in ewes and hemolytic anemia in lamb with death on the first week of life (HERRMANN et al., 2004). However, the most frequent form is the asymptomatic one. Therefore, from an epidemiological point of view, it is the most important one, since the introduction of animals with asymptomatic infection can ensure the persistence of the etiological agent in the herds stricken (ALVES et al., 2012).

Brucellosis is an infectious disease caused by bacteria from the Brucella spp. genre responsible for reproductive disorders in animals, mainly in ruminants (MARTINS et al., 2013).

Transmission happens by the exposure to tissue from infected animals, through placenta, ingestion of water or feed contaminated with Brucella spp. (CASTRO et al., 2005), fomites and artificial insemination (BRASIL, 2006). Both fetuses and fetal annexes from aborted females contaminate the stables, pastures, water and feed, and are the main sources of infection for other animals as well as the human beings (FERNANDES, 2012).

The disease in sheep is characterized by epididymitis in males, abortion in females, occurrence of stillbirth, birth of weak lamb and increase in perinatal mortality, causing a decrease in the reproductive efficiency of the herds (SOUZA et al., 2012). In sheep, it has been described in different patients, being considered one of the main causes of reproductive loss of this animal species originated from the reduction of herd fertility (ESTEIN et al., 2002; CLEMENTINO et al., 2007; FERNANDEZ et al., 2012).

Due to the absence of regional data and the economic importance of sheep production, the purpose of this paper was to seroepidemiological study of Leptospira spp. and Brucella ovis in sheep and dogs from non-mechanized rural properties from the northwestern region in the state of Paraná, Brazil.

\section{Material and Methods}

\section{Sample and study location}

In the period from January to July 2014, blood samples were collected from 542 mixed-breed sheep in reproductive age (above 08 months old) and from 36 mongrel dogs (above 01 year old) from 32 non-mechanized rural properties with reports of reproductive problems in the northwestern region in the state of Paraná, Brazil.

Properties considered as non-mechanized were all the properties observed, where there were no appropriate buildings or facilities (sheep pen and handling corral), with no sanitary, reproductive and feed zootechnical monitoring, where the animals were considered only as a complementary source of income, that is, not exclusively destined to the production of sheep.

At the blood collection, the animals were submitted to anamnesis and no clinical signs were observed for any disease. The collection of blood was performed by veterinarians through the puncture of the jugular vein, collecting approximately $10 \mathrm{~mL}$ blood, which was immediately forwarded to the Laboratory of Preventive Veterinary Medicine and Public Health at Universidade Paranaense (UNIPAR). Upon arrival at the laboratory, the samples were centrifuged in order to obtain their sera. The sera were then divided into three aliquots with equal volume, stored in sterile flasks and kept at $-20^{\circ} \mathrm{C}$ until used in the serological exams.

\section{Diagnoses performed}

For the detection of anti-Leptospira spp. antibodies, the serum samples were submitted to the microscopic agglutination test (MAT) (RYU, 1970 ) at the Laboratory of Leptospirosis from the Department of Preventive Veterinary Medicine 
(DMVP) at State University of Londrina (UEL). A total of 22 reference serovars were used: Australis, Bratislava, Autumnalis, Butembo, Fortbragg, Castellonis, Bataviae, Canicola, Whitcombi, Cinoptery, Grippothyphosa, Hebdomadis, Copenhageni, Icterohaemorrhagiae, Panama, Pomona, Pyrogenes, Hardjo, Wolffi, Shermani, Tarassovi and Sentot, kept at $28^{\circ} \mathrm{C}$ for 5 to 10 days in modified EMJH medium (DIFCO ${ }^{\circledR}$-USA) (ALVES, 1996). Serum samples presenting at least $50 \%$ Leptospiras agglutinated in a dilution of 1:100 were considered reagent and were then diluted in the ratio of two in order to determine the maximum positive dilution.

The analysis of the results considered the serovar presenting the highest agglutinating titer as the most probable, and those presenting co-agglutination in the highest dilution were considered as only reagent for Leptospira spp. (BENITEZ et al., 2010).

In order to detect anti-Brucella ovis antibodies, the serum samples were submitted to the agar gel immunodiffusion assay (AGID) at the Laboratory of Preventive Veterinary Medicine and Public Health at UNIPAR. A commercial kit prepared with Brucella ovis antigen (proteins and lipopolysaccharides) sample REO $198^{\circledR}$, produced by Instituto de Tecnologia do Paraná - Tecpar was used. Samples presenting precipitation line between the well in the test serum and the antigen well were considered reagent, according to instructions from the manufacturer.

\section{Research instrument}

In order to detect variables associated to the different infections, the owners were interviewed, who answered a comprehensive epidemiological questionnaire. The questionnaire contained information on the productive purpose of the herd, exploitation of the property, size of the property, type of sheep breeding, sheep vaccination, sheep breed, animal exchange with other properties, presence of reproductive issues in the herd, frequency of reproductive problems, sheep in contact with other animals from other properties, sheep contact with wild animals, sheep slaughtering on the property, presence of dogs on the property, dog feeding and habits, presence of stray dogs on the property, presence of wild animals on the property, water source used by the animals, if the property shared water with other properties and if the property had veterinary assistance.

\section{Statistical analysis}

In order to verify the association of serological results from the rural properties to the different variables analyzed, the Fischer Exact Test in the Bioestat 5.0 program (AYRES et al., 2007) at significance level of $5 \%$ was used. Variables presenting $\mathrm{p} \leq 0.05$ were considered as statistically significant.

\section{Results}

From the 32 properties studied, 24 (75\%) were considered positive for leptospirosis and 18 (56.25\%) for brucellosis.

For Leptospira spp., a total of 542 sheep and 36 dogs were analyzed, with 61 (11.25\%) and nine (25\%), respectively, being considered reagent at MAT.

Regarding the gender of sheep, 486 were female and 48 male, with 52\% (56/486) female and $10.41 \%$ $(05 / 48)$ being reagent to MAT. Among the 21 female and 15 male dogs, $33.33 \%(07 / 21)$ female and $13.33 \%(02 / 15)$ male were considered reagent to MAT. No statistically significant differences $(\mathrm{p}=0.9936$ - sheep and $\mathrm{p}=0.2518$ dogs) were observed when evaluating the gender variable of the animal with the disease studied.

The most probable serovars detected in sheep were: 21 Hardjo (34.42\%), 12 Butembo (19.67\%), eight Pomona (13.11\%), five Autumnalis $(8.19 \%)$, three Bratislava, Canicola and Pyrogenes (4.91\%) 
each, two Australis (3.27\%) and one Copenhageni, Grippotyphosa, Wolffi, Sentot (1.63\%) each, with titers ranging from 100 to 1600 .

The most probable serovars detected in dogs were: four Butembo (44.44\%), two Autumnalis (22.22\%), one Hardjo, Canicola and Holffi (11.11\%) each, with titers ranging from 100 to 800 .
Regarding the variables analyzed, the exchange of animals among properties $(\mathrm{p}=0.028)$ was associated to leptospiric infection (Table 1).

For Brucella ovis, a total of 542 sheep and 36 dogs were analyzed, with $99(18.26 \%)$ and nine (25\%), respectively, being considered reagent at AGID.

Table 1. Analysed Variables to leptospirosis and brucellosis in sheep and dogs from non-mechanized rural properties in the northwestern region of Paraná, Brazil, 2014.

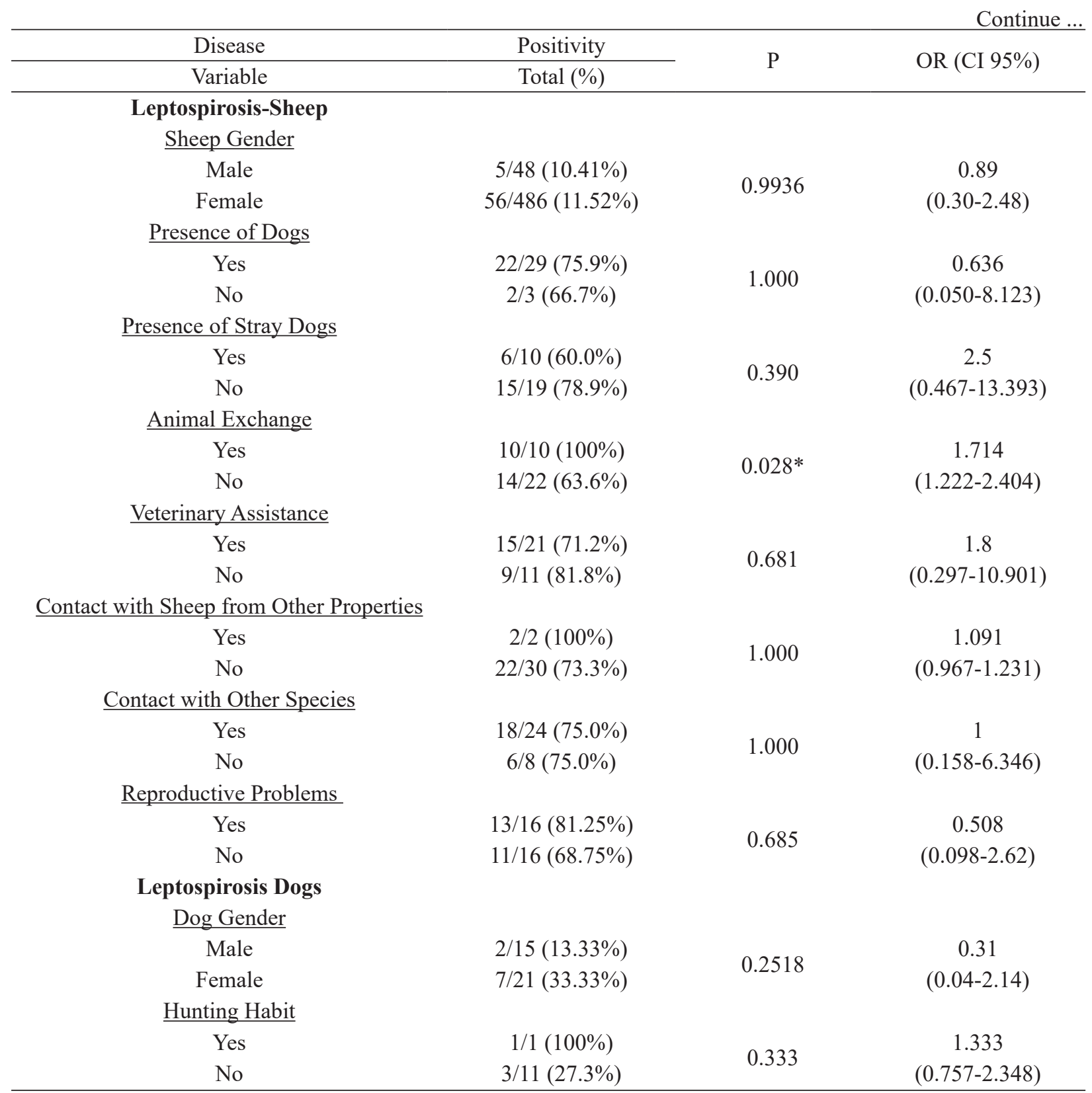


... Continuation

Feed Exposed to the Environment

Yes
No

Presence of Stray Dogs

Yes
No

Contact with Wild Animals

$$
\begin{aligned}
& \text { Yes } \\
& \text { No }
\end{aligned}
$$

Brucellosis Sheep

Sheep Gender

Male

Female

Presence of Dogs

Yes

No

Presence of Stray Dogs

Yes

No

Contact with Wild Animals

Yes

No

Animal Exchange

Yes

No

Veterinary Assistance

Yes

No

Contact with Sheep from Other Properties

Yes

No

$\underline{\text { Reproductive Problems }}$

Yes

No

Brucellosis Dogs

Dog Gender

Male

Female

Feed Exposed to the Environment

Yes

No

Contact with Stray Dogs

$$
\text { Yes } 2 / 4(50.0 \%)
$$

No $\quad 4 / 6(66.7 \%)$

Contact with Wild Animals

$\begin{array}{ll}\text { Yes } & 3 / 4(75.0 \%) \\ \text { No } & 3 / 8(37.5 \%)\end{array}$

1.000

0.875

(0.673-1.137)

0.2

(0.011-6.661)

0.333

$(0.027-4.186)$

1.73

$(0.83-3.56)$

1.625

(0.132-19.986)

0.6

(0.127-2.835)

0.709

(0.137-3.660)

0.208

(0.036-1.214)

0.9

(0.207-3.907)

1.125

(0.955-1.325)

0.6

(0.147-2.455)

0.63

(0.10-3.78)

0.833

(0.583-1.192)

2

(0.150-26.734)

0.2 (0.014-2.911)

p=probability; *Fischer Exact Test; ** Chi-square corrected by Yates (comparison between 1-2 and 1-3) OR=Odds Ratio; $\mathrm{CI}=$ Confidence Interval. 
When compared to the sheep gender, $17.69 \%$ (86/486) female and 27.08\% (13/48) male were considered reagent at AGID. In the dog group, $28.57 \%(06 / 21)$ female and 20\% (03/15) male presented anti-Brucella ovis antibodies. No statistically significant differences $(p=0.1619$ sheep and $p=0.7050$ dogs) were observed when evaluating the gender variable of the animal with the disease studied.

For sheep brucellosis, there were no variables associated to the infection (Table 1).

\section{Discussion}

This paper found $11.25 \%$ prevalence for Leptospira spp. in sheep, with $75 \%$ of the properties being considered positive for the disease. These results are higher than the ones found by Farias et al. (2013) and Alves et al. (2012) in the semiarid region in the state of Paraíba (PB), which presented, respectively, $7.60 \%$ and $5.41 \%$ animals reagent with $27.70 \%$ and $28.20 \%$ properties considered positive. However, they are lower than the ones found by Hashimoto et al. (2010) in the city of Jaguapitã in the state of Paraná, who detected $38.57 \%$ seroreagent animals and $100 \%$ positive properties.

Regarding dogs, a total of $25 \%$ of seroreagent animals in MAT were detected in this work. This result was higher than the studies by Jouglard and Brod (2000) in Pelotas (RS), Martins (2005) in Pirassununga (SP) and Fontes et al. (2013) in Andradina (SP), who detected 2.66\%, 5.10\% and $9.00 \%$, respectively, in MAT. However, they are lower than the ones found by Lemos et al. (2010) and Castro et al. (2011), who detected $37.00 \%$ and $38 \%$ reagent dogs in the cities of Aracaju (SE) and Uberlândia (MG), respectively.

The serological results of this work could have been influenced by the difference in the prevalence of animal leptospirosis in the corresponding study locations, as well as reflecting the period of the study, which might have provided greater or smaller probabilities of the infection affecting the animals (DREER et al., 2013). Another factor that might have also contributed to the low prevalence on this study was the time the blood was collected from the animals, since most of the collection took place during the period considered of draught (May to August). Such assumption is corroborated by the work from Azevedo et al. (2004), where the authors reported that the choice of the period of the year for collecting biological material might have influence on the positivity values of the animals, since the draught season reduces the environmental conditions that favor the survival of the etiological agent, and consequently the dissemination of the disease.

Another environmental factor to be considered for this low prevalence is the fact that the northwestern region of the state of Paraná is located in a region with soil cover characterized by medium to sandy soils, presenting values of over $70 \%$ sand in its composition, granting a high water permeability. This region is denominated as Caiuá Sandstone (EMBRAPA, 1999), which might have contributed for the non-survival of the microorganism, since it needs humidity for its survival.

The antibodies against the most probable serovars detected in sheep were: Hardjo (34.42\%), Butembo (19.67\%) and Pomona (13.11\%). This is similar to the research by Herrmann et al. (2004) in Rio Grande do Sul (RS) and Escócio et al. (2010) in Sorocaba (SP), who detected $28.40 \%$ and $20.45 \%$, also for the Hardjo serovar. However, they differed from the works of Marinho et al. (2012), (Hebdomadis - 18.10\%) in the northwestern region of São Paulo (SP), Alves et al. (2012), (Autumnalis - 49.30\%) in the semiarid region in Paraíba (PB), Carvalho et al. (2011) (Autumnalis - 29.40\%) in the city of Teresina in Piauí (PI), Moraes et al. (2012) (Autumnalis - 66.67\%) in Igarapé-Açu (PA).

The presence of antibodies against different serovars in these studies indicate the presence of different host species in each location studied, since 
Leptospira spp. has a large number of serological variants, which do not present host specificity, but present preferential hosts. This fact can help the characterization of the epidemiology in each location/region (MELO et al., 2010; GRESSLER et al., 2012; FARIAS et al., 2013).

Regarding dogs, antibody against the serovar Butembo was the most prevalent (44.44\%), which differs from the results by Fontes et al. (2013) in Andradina (SP) and Lemos et al. (2010) in Aracaju (SE), who detected Canicola (54.50\%) and Autumnalis $(32.40 \%)$, respectively. In this case, the different serovars detected can be related to the host species that cohabited with dogs, since the serovar Butembo was the most frequent one in this study, emphasizing the importance of rodent control in rural properties, since this animal species is considered the preferential and maintenance host for this serovar (LILENBAUM, 1996; FAINE et al., 1999).

Regarding the variables analyzed in this study for sheep, the exchange of animals among rural properties was associated $(p=0.028)$ to the leptospiric infection, which suggests the possibility of entrance of new animals in the rural properties without previous knowledge of their sanitary status, which could have possibly contributed to the sheep being exposed to the etiological agent.

There were no variable associated to the infection for dogs. However, Fernandes et al. (2009) associated leptospiric infection to the presence of rodents $(p=0.006)$, which might explain the presence of antibody against the Butembo serovar in this study and consequently the importance of rodents in the transmission of leptospirosis to dogs.

For brucellosis, a prevalence of $18.26 \%$ in sheep and $56.25 \%$ positive properties were detected. Higher results were found by Martins et al. (2013) in Tocantins (TO), where they described $31.60 \%$ reagent sheep and $100 \%$ (14) properties were positive to agar gel immunodiffusion assay.
Nonetheless, lower results were found by Souza et al. (2011) in Bahia (BA), who detected 0.72\% sheep and $8.62 \%$ properties positive in AGID. Lower results were also recorded by Silva et al. (2009) in Bahia (BA), Rizzo et al. (2009) in São Paulo (SP), Cunha Filho et al. (2007) in the north of Paraná (PR), who detected 3.27\%, 1.96\%, 1.40\% respectively.

In $43.75 \%$ of the properties studied, there was no presence of animals that were reagent in AGID for Brucella ovis. Similar situation was also found by Salaberry et al. (2011) in Uberlândia (MG) and Marinho et al. (2012), in the northwestern region of the state of São Paulo (SP).

The use of agar gel immunodiffusion assay as the officially recommended technique for the serological diagnosis of $B$. ovis is justified, since according to Johnson and Walker (1992), the reagents present cross-reaction with $B$. canis. This happens because they have a permanently rough colonial morphology, not presenting complete cellular wall lipopolysaccharides, resulting in antigenic similarity.

Among the dogs studied, 25\% were reagent to AGID. Data obtained are higher than the ones by Azevedo et al. (2003) in Santana de Parnaíba (SP), Aguiar et al. (2005) in Monte Negro (RO), Vasconcelos et al. (2008) in Campina Grande (PB) and Bergo et al. (2013) in Umuarama (PR), where they obtained $2.20 \%, 3.60 \%, 2.35 \%$ and $13.04 \%$, respectively.

The high serological prevalence in dogs in this study suggests their exposure to sheep and also to other animal species in the properties, since they are raised loose (AZEVEDO et al., 2003), with free access to the entire property, which increases the chances of having contact with the etiological agent. Another important factor related to the free access in the entire property is the possibility of ingesting fetal remains from infected animals, increasing the chances of infection by Brucella ovis (FERREIRA et al., 2007). 
Regarding reproductive problems, this study did not present association to leptospiric $(\mathrm{p}=0.685)$ and brucellosis $(p=0.722)$ infections, similar to the works by Alves et al. (2012) in the Brazilian semiarid region when studying sheep leptospirosis, and Juliano et al. (2011) in Bahia when studying sheep brucellosis.

The results of this study have shown that leptospirosis and brucellosis are present in the sheep herd and dogs in non-mechanized rural properties in the northwestern region of the state of Paraná (PR), being considered a source of infection to other animals and also to human beings. Moreover, this result is a warning of the zoonotic importance regarding leptospirosis for rural producers and workers, since they are in direct contact with reagent animals.

\section{Conclusion}

With the confirmation of the diagnosis for Leptospira spp. and Brucella ovis in the herd studied, it will be possible to adopt specific therapeutic and prophylaxis conducts for each disease, aiming to improve production.

The problems caused by infectious diseases in this study cause economic impacts, with direct losses related to mortality, morbidity, reduction in zootechnical production, infertility and indirect losses with the development of sanitary programs and trade barriers. Therefore, it would be interesting to develop an "experimental model" study in order to detect losses (financial profitability) by reproductive diseases in sheep, in order to observe the financial impacts generated by brucellosis and leptospirosis in sheep breeding.

\section{Ethics Committee}

This project was approved by the Ethics Committee on Animal Experimentation (CEPEEA) at UNIPAR under protocol no. 25130/2014 on August 22, 2013.

\section{Acknowledgments}

The authors would like to thank the owners, for their constant collaboration. UNIPAR, for the funding granted to this research, and CAPES, for the granting of PROSUP Scholarship.

\section{References}

AGUIAR, D. M.; CAVALCANTE, G. T.; VASCONCELLOS, J. M.; SALGADO, V. R.; CRUZ, T. F.; LABRUNA, M. B.; PINTER, A.; SILVA, J. C. R.; MORAES, Z. M.; CAMARGO, L. M. A.; GENNARI, S. M. Ocorrência de anticorpos anti-Brucella abortus e antiBrucella canis em cães rurais e urbanos do município de Monte Negro, Rondônia, Brasil. Ciência Rural, Santa Maria, v. 35, n. 5, p. 1216-1219, 2005.

ALVES, C. J.; ALCINDO, J. F.; FARIAS, E. E. M.; HIGINO, S. S. S.; SANTOS, F. A.; AZEVEDO, S. S.; COSTA, D. F.; SANTOS, C. S. A. B. Caracterização epidemiológica e fatores de risco associados a leptospirose em ovinos deslanados do semiárido brasileiro. Pesquisa Veterinária Brasileira, Rio de Janeiro, v. 32, n. 6, p. 523-528, 2012.

ALVES, C. J.; VASCONCELOS, S. A.; CAMARGO, C. R. A.; MORAES, Z. M. Influência de fatores ambientais sobre a proporção de caprinos sororreatores para leptospirose em cinco centros de criação do estado da Paraíba, Brasil. Arquivo Instituto de Biologia, São Paulo, v. 63, n.2, p. 11-18, 1996.

AYRES, M.; AYRES JÚNIOR, M.; AYRES, D. L.; SANTOS, A. A. S. BioEstat: aplicações estatísticas nas áreas das ciências biomédicas. Belém: Universidade Federal do Pará, 2007. 364 p.

AZEVEDO, S. S.; ALVES, C. J.; ANDRADE, J. S. L.; BATISTA, C. S. A.; CLEMENTINO, I. J.; SANTOS, F. A. Ocorrência de aglutinina anti-Leptospira em ovinos do estado do Rio Grande do Norte, Brasil. Revista Brasileira de Ciência Veterinária, Niterói, v. 11, n. 3, p. 167-170, 2004.

AZEVEDO, S. S.; VASCONCELlOS, S. A.; ALVES, C. J.; KEID, L. B.; GRASSO, L. M. P. S.; MASCOLII, R.; PINHEIRO, S. R. Inquérito sorológico e fatores de risco para a brucelose por Brucella canis em cães do município de Santana do Paranaíba Estado de São Paulo. Pesquisa Veterinária Brasileira, Rio de Janeiro, v. 23, n. 4, p. 156-160, 2003.

BENITEZ, A.; RODRIGUES, G. G.; GONÇALVES, D. D.; BURKE, J. K.; ALVES, L. A.; MÜLLER, E. E.; FREITAS, J. C. Leptospirose em cães errantes 
encontrados em campus universitário: avaliação sorológica e exame direto da urina. Semina: Ciência Agrária, Londrina, v. 31, n. 1, p. 191-196, 2010.

BERGO, D.; OLIVEIRA, L. A.; RIBEIRO, R. C. L.; ZAMARIAN, T. P.; GONÇALVES, D. D. Anticorpos anti-Brucella canis em cães com suspeita de doença infecto-parasitária da cidade de Umuarama, Paraná. Enciclopédia Biosfera, Goiânia, v. 9, n. 17, p. 205-213, 2013.

BRASIL. Ministério da Agricultura, Pecuária e Abastecimento. Instrução Normativa n²7 de 20 de outubro de 2010. Aprova o teste de polarização fluorescente (TPF) para utilização pelo PNCEBT no diagnóstico da brucelose bovina e bubalina. Diário Oficial [da] União, Brasília, 20 dez. 2010. Seção 1, p. $1-23$.

Ministério da Agricultura, Pecuária e Abastecimento. Portaria $\mathrm{n}^{\circ} 102$ de 17 de dezembro de 2004. Dispõe sobre o Plano Nacional de Vigilância e Controle da Epididimite Ovina_Brucella ovis. Diário Oficial [da] União, Brasília, 17 de dezembro 2004. Seção 1, p. 24.

Ministério da Agricultura, Pecuária e Abastecimento. Programa Nacional de controle $e$ erradicação da brucelose e tuberculose_ PNCEBT. Brasília, 2006. 190 p. (Manual técnico).

CARVALHO, S. M.; GONÇALVES, L. M. F.; MACEDO, N. A.; GOTO, H.; SILVA, S. M. M. S.; MINEIRO, A. L. B. B.; KANASHIRO, E. H. Y.; COSTA, F. A. L. Infecção por leptospiras em ovinos e caracterização da resposta inflamatória renal. Pesquisa Veterinária Brasileira, Rio de Janeiro, v. 31, n. 8, p. 637-642, 2011.

CAStro, H. A.; GOnZAlEZ, S. R.; PRAT, M. I. Brucelosis: una revisión prática. Acta Bioquímica Clínica Latino-Americana, Buenos Aires, v. 39, n. 2, p. 203-216, 2005.

CASTRO, J. R.; SOUZA, M. S.; SALABERRY, S. R. S.; NAVES, J. H. F. F.; GUIMARÃES, E. C.; LIMARIBEIRO, A. M. C. Leptospirose canina relacionada à sazonalidade no município de Uberlândia, MG. Ciência Animal, Goiânia, v. 21, n. 2, p. 77-86, 2011.

ClementinO, I. J.; ALVES, C. J.; AZEVEDO, S. S.; AULIN, L. M.; MEDEIROS, K. A. Inquérito soroepidemiológico e fatores de risco associados à infecção por Brucella ovis em carneiros deslanados do semiárido da Paraíba. Pesquisa Veterinária Brasileira, Rio de Janeiro, v. 27, n. 4, p. 137-143, 2007.
CUNHA FILHO, L. F. C.; LEUZZI JUNIOR, L. A.; SILVA, L. C.; AGOTTANE, J. V. B.; OKANO, W.; STERZZA, F. M. A.; ZANIN, R. Ocorrência de ovinos reagentes a prova de imunodifusão em gel de ágar, para Brucella ovis, em propriedades da região Norte do Paraná. Ciência Biologia e Saúde, Londrina, v. 9, n. 1, p. 67-70, 2007.

DREER, M. K. P.; GONÇALVES, D. D.; CAETANO, I. C. S.; GERÔNIMO, E.; MENEGAS, P. H.; BERGO, D.; MORI, F. M. R. L.; BENITEZ, A.; FREITA, J. C.; EVERS, F.; NAVARRO, I. T.; MARTINS, L. A. Toxoplasmosis, leptospirosis and brucellosis in stray dogs housed at the shelter in Umuarama municipality, Paraná, Brazil. Journal of Venomous Animals and Toxins including Tropical Diseases, Botucatu, v. 19, n. 1, p. 1923,2013 .

EMPRESA BRASILEIRA DE PESQUISA AGROPECUÁRIA - EMBRAPA. Centro Nacional de Pesquisa de Solos. Sistema brasileiro de classificação dos solos. Brasília: Embrapa, 1999. 421 p.

ESCÓCIO, C.; GENOVEZ, M. E.; CASTRO, V.; PIATTI, R. M.; GABRIEL, F. H. L.; CHIEBAO, D. P.; AZEVEDO, S. S.; VIEIRA, S. R.; CHIBA, M. Influência das condições ambientais na transmissão da leptospirose entre criações de ovinos e bovinos da região de Sorocaba, SP. Arquivo Instituto Biológico, São Paulo, v. 77, n. 3, p. 371-379, 2010.

ESTEIN, S. M.; BALDI, P. C.; BOWDER, R. A. Comparison of serological tests based on ociter membrane or internal antigens for detecting antibodies to Brucella ovis in infected flocks. Journal of Veterinary Diagnostic Investigation, Guelph, v. 14, n. 5, p. 407-411, 2002.

FAINE, S.; ADLER, B.; BOLIN, C.; PEROLAT, P. Leptospira and leptospirosis. $2^{\text {th }}$ ed. Melbourne: MediSci, 1999. $272 \mathrm{p}$.

FARIAS, A. E. M.; HIGINO, S. S. S.; AZEVEDO, S. S.; COSTA, D. F.; SANTOS, F. A.; CORREIA, E. L.; SANTOS, C. S. S. B.; ALVES, C. J. Epidemiological evaluation of reproductive infectious agentes in sheep in the Brazilian Semiarid. World Journal of Veterinary Science, Pasquistan, v. 1, n. 1, p. 13-17, 2013.

FERNANDES, C. E. Papel do ovino na cadeia epidemiológica da leptospirose pela Leptospira spp sorovar hardjo: fatores de risco que envolvem a infecção e transmissão entre ovinos e bovinos. 2009. Dissertação (Mestrado em Sanidade, Segurança Alimentar e Ambiental no Agronegócio) - Instituto Biológico. Agência Paulista de Tecnologia dos Agronegócios, São Paulo. 
FERNANDES, M. O. L. Brucelose dos pequenos ruminantes: estudos de focos na área administrativa da divisão de intervenção veterinária de Vila Real. 2012. Dissertação (Mestrado Integrado em Medicina Veterinária) - Faculdade de Medicina Veterinária. Universidade Técnica de Lisboa, Lisboa.

FERNANDEZ, L. A. R.; ARREBOLA, D. F. A.; SANTIESTEBAN, N. B.; TORUNO, W. J.; ABREÚ, B. Y. V.; FERNADEZ, Y. E. S.; BOURZAC, J. F. I. Leptospirosis, una revisión actualizada. Revista Veterinária Argentina, Buenos Aires, v. 24, n. 291, p. $1-53,2012$.

FERREIRA, T.; MANDELBAUM, M. A.; MARQUES, A. P. L.; TORRES, H. M. T.; FIGUEIREDO, M. J.; SERRA, C. M. B.; AQUINO, M. H. C. Inquérito sorológico da brucelose canina através da utilização de antígeno externo e interno de Brucella canis e Brucella ovis Serodiagnosis of canine brucellosis using external and internal antigens of Brucella canis and Brucella ovis. Revista Brasileira de Ciências Veterinária, Niterói, v. 14, n. 3, p. 167-168, 2007.

FONTES, A. M. M.; RUFINO, C. A.; ASSUNÇÃO, T. M.; SILVA, E. S. S.; BELARMINO, D. A.; SANTOS, D. G.; LOPES, P. D.; BARBUDO FILHO, J. Soroprevalência de leptospirose em cães no município de Andradina/SP. Ciência Agrária e Saúde, Andradina, v. 9, n. 1, p. 21-25, 2013.

GONÇALVES, D. D.; BENITEZ, A.; LOPES-MORI, F. M. R.; ALVES, L. A.; FREIRE, R. L.; NAVARRO, I. T.; SANTANA, M. A. Z.; SANTOS, L. R. A.; CARREIRA, T.; VIEIRA, M. L.; FREITAS, J. C. Zoonoses in humans from small rural properties in Jataizinho, Parana, Brazil. Brazilian Journal of Microbiology, São Paulo, v. 44, n. 1, p. 125-131, 2013.

GRESSLER, M. A.; SCHEID, R.; MARTINS, D.; FARFA, L.; KRUG, S. B. F. Leptospirose e exposição ocupacional: um estudo no município de santa Cruz do Sul/RS. Revista de Epidemiologia e Controle de Infecções, Santa Cruz do Sul, v. 2, n. 2, p. 51-54, 2012.

HASHIMOTO, V. Y.; GARCIA, J. L.; SPOHR, K. A. H.; SILVA, F. G.; ALVES, L. A.; FREITAS, J. C. Prevalência de anticorpos anti-Leptospira spp. em bovinos, caninos, equinos, ovinos e suínos no município de Jaguapitã, Estado do Paraná, Brasil. Arquivo Instituto Biológico, São Paulo, v. 77, n. 3, p. 521-524, 2010.

HERRMANN, G. P.; LAGE, A. P.; MOREIRA, E. C.; HADDAD, J. P. A.; RESENDE, J. R.; RODRIGUES, R. O.; LEITE, R. C. Soroprevalência de aglutininas antiLeptospira spp. em ovinos nas mesorregiões Sudeste e Sudoeste do Estado do Rio Grande do Sul, Brasil. Ciência Rural, Santa Maria, v. 34, n. 2, p. 443-448, 2004.
HIGINO, S. S.; AZEVEDO, S. S. Leptospirose em pequenos ruminantes: situação epidemiológica atual no Brasil. Arquivo Instituto Biológico, São Paulo, v. 81, n. 1, p. 86-94, 2014.

JOHNSON, C. A.; WALKER, R. D. Clinical signs and diagnosis of Brucella canis infeccion. Compendium on Continuing Education for the Practicing Veterinarian, Yardley, v. 14, n. 6, p. 763-772, 1992.

JOUGLARD, S. D. D.; BROD, C. S. Leptospirose em cães: prevalência e fatores de risco no meio rural do município de Pelotas, RS. Arquivo Instituto Biológico, São Paulo, v. 67, n. 2, p. 181-185, 2000.

JULIANO, R. S.; SILVA, M. S. P.; PELLEGGRIN, A. O.; LIMA, M. F. M. T.; SILVA, R. A. M. S. Prevalência de brucelose ovina no município de Corumbá-MS. Veterinária e Zootecnia, Botucatu, v. 18, n. 4, p. 827-830, 2011.

LEMOS, J. P.; MELO, C. B.; VIEGAS, A. S. Analise sorológica de Leptospira spp em cães errantes no município de Aracaju. Revista Cientifica Eletrônica de Medicina Veterinária, Garça, ano 8, n. 14, p. 1125-1141, 2010.

LILENBAUM, W. Atualização em leptospirose bovina. Revista Brasileira de Medicina Veterinária, Rio de Janeiro, v. 18, n. 1, p. 9-13, 1996.

MARINHO, M.; MENDES, L. C. N.; KANETO, C. N.; TAPARO, C. V.; BERNARDES, J. O. R.; LOMBARDI, A. L.; PERRI, S. H. V.; BALDASSO, A. B.; RIBEIRO, M. M. Perfil de aglutininas anti-Leptospira e antiBrucella e condições sanitárias de ovinos da região Noroeste do estado de São Paulo, Brasil. Veterinária e Zootecnia, Botucatu, v. 19, n. 4, p. 593-600, 2012.

MARTINS, L. S. Situação epidemiológica da leptospirose bovina, canina e humana na área rural do municipio de Pirassununga, SP. 2005. Tese (Doutorado em Epidemiologia Experimental e Aplicada às Zoonoses) - Faculdade de Medicina Veterinária e Zootecnia. Universidade de São Paulo, São Paulo.

MARTINS, N. E. X.; ALMEIDA, J. D. M.; SILVA, M. G.; SOUSA, M. G.; MATHIAS, L. A.; ALMEIDA, K. S. Prevalência de anticorpos anti-Brucella ovis e antiBrucella abortus em ovinos do município de Colinas, Tocantins, Brasil. Revista de Patologia Tropical, Goiânia, v. 42, n. 2, p. 147-160, 2013.

MELO, L. S. S.; CASTRO, M. B.; LEITE, R. C.; MOREIRA, E. C.; MELO, C. B. Principais aspectos da infecção por Leptospira sp em ovinos. Ciência Rural, Santa Maria, v. 40, n. 5, p. 1235-1241, 2010. 
MINISTÉRIO DA AGRICULTURA PECUÁRIA E ABASTECIMENTO - MAPA. Programa Nacional de Sanidade dos Caprinos e Ovinos. Brasília: 2012. Disponível em: <http://www.agricultura.gov.br/ portal/page?_pageid=33,982143\&_dad=portal $\&$ schema=PORTAL $>$. Acesso em: 5 out. 2014.

MORAES, C. C. G.; GUERREIRO, A. N.; KURODA, R. B. S.; SOUZA, V. A. F.; MENESES, A. M. C.; VASCONCELLOS, A. S. Inquérito sorológico para leptospirose em rebanhos de ovinos no município de Igarapé-Açu, Estado do Pará. Revista Ciência Agrarial Amazonian Journal, Belém, v. 55, n. 1, p. 58-60, 2012.

RADOSTITS, O. M.; MAYHEW, I. G. J.; HOUSTON, D. M. Exame clínico e diagnóstico em veterinária. Rio de Janeiro: Guanabara Koogan, 2002. 591 p.

RIZZO, H.; GREGORY, L.; PINHEIRO, E. S.; CARVAlHO, A. F.; SANTANA, L.; SILVA, L. M. P. Incidência de Brucella ovis em ovinos com histórico de distúrbios reprodutivos no estado de São Paulo, Brasil. Ciência Animal Brasileira, Goiânia, v. 8, p. 591-596, 2009. Suplemento. 1

RYU, E. Rapid microscopic agglutination test for Leptospira without non-specific reaction. Bulletin Office International Epizooties, Paris, v. 1-2, n. 73, p. 49-58, 1970.

SALABERRY, S. R. S.; PAULIN, L. M.; SANTANA, R. L.; CASTRO, J. R.; RIBEIRO, A. M. C. L. Pesquisa de anticorpos anti-Brucella abortus e anti-Brucella ovis em ovinos no município de Uberlândia, MG. Arquivo Brasileiro Medicina Veterinária e Zootecnia, Belo Horizonte, v. 63, n. 4, p. 1022-1024, 2011.
SANTOS, F. A.; HIGINO, S. S. S.; COSTA, D. F.; FARIAS, A. E. M.; ALVES, F. A. L.; PAULIN, L. M.; ALVES, C. J. Caracterização epidemiológica e fatores de risco associados a infecção por Brucella ovis em ovinos deslanados do semiárido paraibano. Pesquisa Veterinária Brasileira, Rio de Janeiro, v. 33, n. 4, p. 459-463, 2013.

SILVA, N. S.; BARROS, I. N.; DASSO, M. G.; ALMEIDA, M. G. A. R.; LABORDA, S. S.; ANUNCIAÇÃO, A. V. M.; MOREIRA, E. L. T.; SILVA, A. E. L.; OLIVEIRA, E. M. D. Detecção de anticorpos anti-Brucella ovis em ovinos do Estado da Bahia. Revista Brasileira de Saúde e Produção Animal, Salvador, v. 10, n. 4, p. 852-859, 2009.

SOUZA, T. S.; COSTA, J. N.; MARTINEZ, P. M.; LIMA, C. C. V.; ARAÚJO, B. R.; COSTA NETO, A. O.; ANUNCIAÇÃO, A. V. M.; ALMEIDA, M. G. A. R.; PINHEIRO, R. R. Inquérito soro-epidemiológico de Brucella ovis em rebanhos ovinos no semiárido baiano. Arquivo Instituto Biológico, São Paulo, v. 79, n. 2, p. 277-281, 2012.

. Inquérito soro-epidemiológico de Brucella ovis em rebanhos ovinos no semiárido baiano. Veterinária e Zootecnia, Botucatu, v. 18, n. 4, p. 697-700, 2011.

VASCONCELOS, R. T. J.;ALVES, C. J.; CLEMENTINO, I. J.; ARAÚJO NETO, J. O.; ALVES, F. A. L.; BATISTA, C. S. A.; BERNARDI, F.; SOTO, F. R. M.; OLIVEIRA, R. M.; AZEVEDO, S. S. Soroprevalência e fatores de risco associados à infecção por Brucella canis em cães da cidade de Campina Grande, estado da Paraíba. Revista Brasileira de Saúde e Produção Animal, Salvador, v. 9, n. 3, p. 436-442, 2008. 